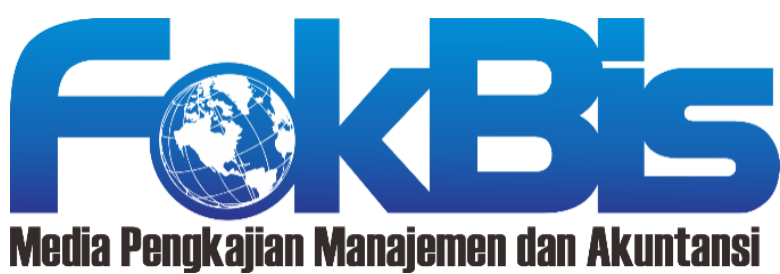

http://journal.stieputrabangsa.ac.id/index.php/fokbis/index

ISSN: 2623-2480/ P-ISSN: 1693-5209

\section{Analisis Theory of Planned Behavior dalam Memprediksi Niat Akuntan dalam Memperoleh Gelar Chartered Accountant di Wilayah Jawa Tengah}

\author{
Dwi Artati $^{1}$, Eni Kaharti ${ }^{2}$, Ika Susilowati ${ }^{3}$ \\ 1,2,3) Universitas Putra Bangsa \\ email: dwiartati1709@gmail.com ${ }^{1}$
}

\section{Article Information}

\section{History of Article:}

Received September 9th 2020

Accepted May 11th 2021

Published July $31^{\text {st }} 2021$

\section{DOI:}

10.32639/fokusbisnis.v19i2.833

\begin{abstract}
ABSTRAK
Abstrak Tujuan dari penelitian ini adalah untuk mengetahui minat dari para akuntan dalam memperoleh gelar Chartered accountant. Melalui penerapan theory of planned behavior (TPB), penelitian ini bermaksud untuk menemukan bukti empiris tentang pengaruh faktor persepsi dan sikap, norma subjektif, dan kontrol perilaku persepsian akuntan terhadap minat untuk memperoleh gelar Chartered accountant. Sample yang digunakan adalah mahasiswa yang sedang menempuh pendidikan akuntan di Jawa tengah. Pada penellitian ini pengujian variabelnya semua sudah lolos uji asumsi klasik dan validitas dan reliabilitas sebelum dilaksanakan pengujian hipotesis yang menggunakan uji regresi dengan alat analisis SPSS 23. Dimana hasil penelitian ini menemukan bahwa variabel sikap tidak berpengaruh terhadap behavioral intention,variabel norma subjektif tidak berpengaruh terhadap behavioral intention, variabel Kontrol perilaku berpengaruh terhadap behavioral intention dalam memperoleh gelar Chartered accountant di Jawa Tengah.
\end{abstract}

Kata Kunci: Chartered accountant, Sikap, Norma Subjektif, Kontrol Perilaku

\begin{abstract}
The purpose of this study was to determine the interest of accountants in obtaining the title of Accountant. Through the application of planned behavior theory (TPB), this research is based on empirical evidence about the influence of perceptions and attitudes, subjective norms, and control of accountants' perceived behavior on the interest in obtaining the title of Accountant. The example used is students who are currently studying accountants in Central Java. In this study, all oxf the variables tested had passed the classical assumptions and validity and reliability before testing the hypothesis using the regression test with the SPSS 23 analysis tool. Where the results of this study found that the attitude variable (X1) had no effect on behavior intention, the subjective norm variable (X2) has no effect on behavioral intention, variable Kontrol perilaku affects behavior intention in obtaining the title Chartered accountant in Central Java.
\end{abstract}

Keywords: Chartered accountant, Attitude, Subjective Norms, Perceived Behavioral Control 


\section{PENDAHULUAN}

Semakin berkembangnya dunia bisnis saat ini, makin dibutuhkan akuntan akuntan yang handal agar dapat menghasilkan laporan keuangan yang dapat digunakan sebagai dasar dalam pengambilan keputusan. Hal ini tidak lepas dari keberadaan akuntansi. Akuntansi sering disebut sebagai bahasa bisnis atau mungkin akan lebih tepat jika disebut " bahasa pengambilan keputusan". Semakin kita kuasai bahasa ini, akan semakin baik pula kita menangani berbagai aspek keuangan dalam kehidupan (Yusup:5)

Menjelang memasuki era Masyarakat Ekonomi ASEAN (MEA) pada tahun 2015, Indonesia adalah salah satu Negara yang ikut serta berkompetisi didalamnya. Era memasuki Masyarakat Ekonomi (MEA) maka sumber daya tenaga kerja di negara negara ASEAN dapat memasuki wilayah ASEAN dengan tidak terkecuali. Apalagi bagi tenaga kerja yang memiliki keahlian dan mempunyai sertifikasi profesi internasional. Seperti halnya untuk profesi akuntan.

ACCA merupakan singkatan dari Association of Chartered Certification Accountants, didirikan pada tahun 1904, merupakan asosiasi global untuk akuntan profesional. ACCA saat ini memiliki 162 ribu anggota dan 428 ribu siswa di 173 negara. ACCA memiliki 91 kantor di seluruh dunia dan bekerja sama dengan lebih dari 8.500 perusahaan yang diakui di seluruh dunia.(Swa.co.id). Mengingat pentingnya memiliki sertifikat profesi internasional dalam berkompetisi memasuki wilayah pasar bebas maka akan dibutuhkan para akuntan akuntan yang memiliki keahlian yang ditunjukkan dengan dimilikinya Sertifikat professional tersebut yaitu sertifikat Chartered accountant. Dengan dimilikinya sertifikat Chartered accountant maka peluang untuk bekerja didalam maupun diluar negeri karena akuntan dengan bersertifikat internasional memiliki prosek yang bagus di Wilayah ASEAN. Jumlah akuntan di negaranegara ASEAN terbilang sedikit jika dibandingkan jumlah penduduk dan kebutuhan akuntan disetiap Negara (IAI dan www.asean.org).

Theory of Planned Behavior (TPB) adalah model berbasis niat (intention) yang dikembang oleh Ajzen (1991). Teori ini merupakan pengembangan dari Theory of Reasoned Action (TRA) yang dikenalkan oleh Fishbein (1967) dan kemudian dikembangkan oleh Ajzen dan Fishbein (1975). Theory ini merupakan teori yang digunakan untuk menjelaskan maksud seseorang untuk melakukan perilaku tertentu. Niat merupakan indikasi seberapa keras seseorang bersedia untuk mencoba berbagai upaya mereka merencanakan untuk melakukan perilaku. (Ajzen dan Driver, 1992). Mengingat jumlah akuntan yang bersertifikat masih sedikit diwilayah Negara Negara ASEAN dibandingkan dengan jumlah penduduk dan kebutuhan akuntan disetiap Negara maka perlu dipelajari kembali seberapa niat mereka terhadap Chartered accountant.

Dengan menggunakan theory of reasoned action (TRA), Felton et al. (1995) meneliti hubungan antara sikap (attitude) terhadap chartered accountant dengan niat mahasiswa untuk berkarier pada chartered accountant. Penelitian yang dilakukan pada 856 mahasiswa bisnis tingkat akhir menunjukkan sikap (attitude) terhadap chartered accountant berhubungan secara signifikan terhadap keputusan mahasiswa untuk berkarier sebagai chartered accountant.

\section{KAJIAN LITERATUR DAN PENGEMBANGAN HIPOTESIS}

\section{Theory of Planned Behavior}

Teori perilaku rencanaan (theory of planned behavior atau TPB) merupakan pengembangan lebih lanjut dari theory of reasoned action (TRA) (Ajzen, 1991) dalam Mahardhika \& Zakiyah (2020). Theory of Reasoned Action (TRA) menjelaskan tentang perilaku yang berubah berdasarkan hasil dari niat perilaku, dan niat perilaku dipengaruhi oleh norma sosial dan sikap individu terhadap perilaku (Eagle, Dahl, Hill, Bird, Spotswood, \& Tapp, 2013, hal. 123). Theory of Reasoned Action (TRA) adalah salah satu teori yang dikenal sebagai teori fundamental dalam menjelaskan perilaku. Sikap dapat ditempatkan kedalam variabel mempengaruhi, dimana seorang menilai objek tertentu dan memiliki perasaan khusus terhadap 
objek tersebut. Perilaku dapat dilihat sebagai tindakan obseravasi dari subjek, keyakinan adalah representasi dari pengetahuan seseorang terhadap suatu subjek (menghubungkan objek untuk atribut tertentu) dan niat perilaku mengacu pada niat seseorang untuk melakukan berbagai perilaku (Fishbein dan Ajzen, 1975). Menurut (Lee \& Kotler, 2011, hal. 198), Theory of reason action yang dikembangkan oleh Ajzen dan Fishbein, menyatakan bahwa prediksi terbaik mengenai perilaku seseorang adalah berdasarkan minat orang tersebut. Minat perilaku didasari oleh 2 faktor utama, yaitu : kepercayaan individu atas hasil dari perilaku yang dilakukan dan persepsi individu atas pandangan orang-orang terdekat individu terhadap perilaku yang dilakukan.

Namun TRA itu sendiri sebenarnya juga mempunyai kelemahan karena dengan adanya penekanan pada faktor norma subjektif yang dianggap terlalu melemahkan faktor individu sebagai pengendali atas tingkah lakunya sendiri. Ini menimbulkan kurang akuratnya teori tersebut. Oleh karena itu, TRA dikembangkan menjadi Theory of planned Behavior (TPB) dengan menambahkan kontrol perilaku (perceived behavioral control) sebagai penentu niat seseorang. Theory of Planned Behavior (TPB) mengatasi kekurangakuratan dalam Theory of Reasoned Action melalui penelitian-penelitian yang dilakukan oleh Fishbein dan Ajzen. Theory of Planned Behavior (TPB) menjelaskan bahwa perilaku seseorang tidak hanya dikendalikan oleh dirinya sendiri, tetapi juga kontrol yang ketersediaan sumber daya dan kesempatan tertentu (perceived behavioral control) (Ajzen 1988).

Persepsi pengendalian perilaku (perceived behavioral control) adalah variabel konstruk yang ditambahkan dalam upaya melengkapi keterbatasan yang dimiliki oleh individu dalam melakukan suatu perilaku. Persepsi pengendalian perilaku (perceived behavioral control) ini adalah konstruk yang belum ada dalam Theory of Planned Behavior (TPB). Jadi dalam Theory of Reasoned Action ini persepsi individu terhadap kontrol yang dapat dilakukan, yang bersumber pada keyakinan terhadap kontrol tersebut ikut menentukan diaksanakan atau tidaknya suatu perilaku selain ditentukan oleh sikap dan norma subjektif. Ini Ajzen menyimpulkan bahwa TRA hanya berlaku bagi tingkah laku yang berada dibawah kontrol penuh individu, namun tidak sesuai untuk menjelaskan tingkah laku yang tidak sepenuhnya dibawah kontrol individu, karena ada faktor yang menghambat atau memfasilitasi realisasi niat kedalam tingkah laku. Padahal sebelumnya banyak sekali penelitian dibidang sosial yang sudah membuktikan bahwa TRA adalah teori yang cukup memadai dalam memprediksi tingkah laku.

\section{Chartered Accountant}

Chartered Accountant adalah Akuntan yang bersertifikasi internasional dimana akuntan ini menjadi soerang seorang akuntan profesional dengan keahlian dan kompetensi yang diakui,dan juga terdaftar sebagai akuntan beregister negara. Register negara akuntan adalah sebuah daftar dengan nomor dan nama seseorang yang mempunyai hak untuk menggunakan gelar Akuntansi sebagaimana disebutkan dalam Peraturan Menteri Keuangan Republik Indonesia Nomor 25/Pmk.01/2014 Tentang Akuntan Beregister Negara pasal 4 ayat 2 menyatakan: “...dapat mengikuti ujian sertifikasi akuntan profesional, seseorang harus memenuhi salah satu persyaratan sebagai berikut: a) Memiliki pendidikan paling rendah diploma empat (D-IV) atau sarjana (S-1) di bidang akuntansi yang diselenggarakan oleh perguruan tinggi Indonesia atau luar negeri yang telah disetarakan oleh instansi yang berwenang sesuai dengan ketentuan peraturan perundang-undangan di bidang pendidikan; b) Memiliki pendidikan magister (S-2) atau doktor (S-3) yang menekankan penerapan praktik-praktik akuntansi dari perguruan tinggi Indonesia atau perguruan tinggi luar negeri yang telah disetarakan oleh instansi yang berwenang sesuai dengan ketentuan peraturan perundang-undangan di bidang pendidikan; c) Mengikuti pendidikan profesi akuntansi; atau d) Memiliki sertifikat teknisi akuntansi level 6 (enam) berdasarkan kerangka kualifikasi nasional Indonesia sesuai dengan ketentuan peraturan perundang-undangan". 
Sertifikasi Chartered Accountant dapat dimiliki melalui ujian yang disediakan oleh asosiasi yang berwenang. Ujian yang diselenggarakan akan mencakup tujuh matakuliah sesuai ketentuan. Peserta ujian yang lolos seluruh matakuliah akan diwajibkan untuk melakukan praktisi selama dua atau tiga tahun dan mengikuti kegiatan Pendidikan Profesional Berkelanjutan (PPL) minimal 120 Satuan Kredit PPL (SKP) untuk meningkatkan kompetensi yang dimiliki.

Pelatihan profesional dalam penelitian Kwarto dan Saputra (2015) dinyatakan memiliki pengaruh positif signifikan pada minat mahasiswa akuntan untuk berkarir sebagai akuntan profesional sertifikasi CA memerlukan waktu yang tidak singkat untuk memenuhi ujian dengan tujuh matakuliah dan menyelesaikan dua atau tiga tahun untuk pengalaman praktik. Individu juga diwajibkan untuk mengikuti PPL setelah selesai ujian untuk meningkatkan kompetensinya. Felton et al.(1995) Mahasiswa yang berniat menjalani karier sebagai chartered accountant memiliki sikap yang positif terhadap profesi chartered accountant. Mahasiswa yang berniat menjalani karier sebagai chartered accountant memercayai bahwa benefit yang akan mereka peroleh akan lebih besar dibandingkan cost yang mereka berikan bila menjadi chartered accountant. Law (2010) Faktor intrinsik (attitude toward behaviour), fleksibilitas karier, parental influence (subjective norm) berpengaruh secara positif dan signifikan terhadap mahasiswa yang berniat menjalani karier pada CPA dan profesi akuntansi lainnya. Gender berpengaruh secara negatif signifikan terhadap mahasiswa yang berniat menjalani karier pada CPA dan profesi akuntansi lainnya. Faktor financial reward menunjukkan hasil pengaruh yang negative dan tidak signifikan terhadap mahasiswa yang berniat menjalani karier pada CPA an profesi akuntansi lainnya.. Sedangkan motivasi mencari ilmu, biaya pendidikan dan lama pendidikan tidak memiliki pengaruh signifikan tehadap minat. Solikhah (2014) Sikap terhadap perilaku, norma subjektif, dan persepsi pengendalian perilaku berpengaruh terhadap niat untuk mengambil CPA.

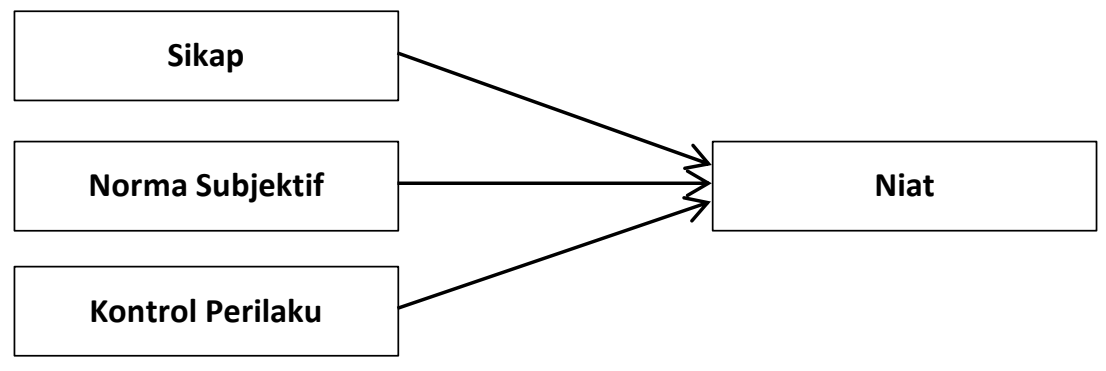

Gambar 1. Model Penelitian

$\mathrm{H}_{1}$ : Sikap berpengaruh terhadap niat akuntan dalam memperoleh gelar chartered accountant

$\mathrm{H}_{2}$ : Norma subyektif berpengaruh terhadap niat akuntan dalam memperoleh gelar chartered accountant

$\mathrm{H}_{3}$ : Kontrol perilaku berpengaruh signifikan terhadap niat akuntan dalam memperoleh gelar chartered accountant 


\section{METODE PENELITIAN}

Penelitian ini menggunakan pendekatan dengan metode kuantitatif. Metode yang digunakan dalam penelitian ini adalah explanatory research, yaitu menekankan hubungan antara variabel-variabel penelitian (variabel dependen dan variabel independen) dan pengujian hipotesis (hypothesis testing) untuk menguji hipotesis yang diajukan.

\section{Populasi dan Sampel}

Populasi dalam penelitian adalah para calon akuntan yang sedang menempuh pendidikan profesi akuntan diwilayah Jawa Tengah. Dalam penelitian ini semua populasi yang ada dijadikan sampel dalam penelitian.

\section{Sumber Data}

Sumber data primer diperoleh secara langsung dari responden penelitian dan sumber data sekunder diperoleh dari IAI, literature serta sumber kepustakaan yang mempunyai relevansi dengan penelitian.

\section{Metode Pengumpulan Data}

Pengumpulan data primer dengan menggunakan kuesioner terstruktur yang diberikan kepada reponden penelitian. Responden akan menilai setiap pertanyaan dengan menggunakan skala likert 5 poin. (1) Sangat Setuju (2) Setuju (3) Netral (4) Tidak Setuju (5) Sangat Tidak Setuju.

\section{Teknik Analisis Data}

Hipotesis dalam penelitian ini akan diuji dengan alat analisis regresi berganda menggunakan SPSS versi 23.

\section{HASIL DAN PEMBAHASAN}

\section{Deskriptif Penyebaran Kuesioner}

Tabel 1. Penyebaran dan Pengembalian Kuesioner

\begin{tabular}{ccc}
\hline Keterangan & Jumlah Kuesioner & Prosentase \\
\hline Kuesioner disebarkan & 58 & $100 \%$ \\
Kuesioner tidak kembali & $(2)$ & $3,45 \%$ \\
Kuesioner yang diolah & 56 & $96,55 \%$ \\
\hline
\end{tabular}

Sumber: data diolah, 2020

Berdasarkan tabel di atas dapat diketahui bahwa jumlah kuesioner yang disebar sebanyak 58 kuesioner dan kuesioner yang tidak kembali sebanyak 2 kuesioner sehingga kuesioner yang dapat diolah sebanyak 56 kuesioner. 


\section{Demografi Responden}

Tabel 2. Informasi Karakteristik Responden

\begin{tabular}{llrr}
\hline Keterangan & & Jumlah & \multicolumn{1}{c}{ Persentase } \\
\hline Jenis Kelamin & Laki-laki & 28 & $50 \%$ \\
& Perempuan & 28 & $50 \%$ \\
\cline { 2 - 4 } & Total & 56 & $100 \%$ \\
\hline Umur & $21-30$ th & 35 & $62,5 \%$ \\
& $31-40$ th & 10 & $17,9 \%$ \\
& $41-50$ th & 10 & $17,9 \%$ \\
& $>50$ th & 1 & $1,8 \%$ \\
\cline { 2 - 4 } & Total & 56 & $100 \%$ \\
\hline Status Responden & Bekerja & 47 & $83,9 \%$ \\
& Belum Bekerja & 9 & $16,1 \%$ \\
\cline { 2 - 4 } & Total & 56 & $100 \%$ \\
\hline Status sebagai & Aktif & 52 & $92,9 \%$ \\
mahasiswa & Tidak Aktif & 56 & $7,1 \%$ \\
\cline { 2 - 4 } & Total & $100 \%$ \\
\hline
\end{tabular}

Sumber: data diolah, 2020

Berdasarkan tabel di atas dapat dilihat sebaran responden berdasarkan jenis kelamin, umur, status responden dan status sebagai mahasiswa.

\section{Uji Validitas}

Uji validitas dapat dilakukan dengan membandingkan nilai $r$ hitung dengan $r$ tabel untuk degree of freedom $(\mathrm{df})=\mathrm{n}$-2. Jika $r$ hitung lebih besar dari $r$ tabel dan bernilai positif maka pertanyaan atau indikator tersebut dinyatakan valid. Jumlah sampel yang diolah ( $n$ ) dalam penelitian ini sebanyak 56 responden dan besarnya df dapat dihitung menjadi 56-2= 54 dengan df 54 dan alpha 0,05 didapat $r$ tabel senilai 0,2632 . Hasil validitas dalam penelitian ini dapat dilihat pada tabel berikut :

Tabel 3. Hasil Uji Validitas Variabel Sikap

\begin{tabular}{ccccc}
\hline Butir & r hitung & r tabel & signifikansi & Keterangan \\
\hline X11 & 0,726 & 0,2632 & 0,000 & Valid \\
X12 & 0,742 & 0,2632 & 0,000 & Valid \\
X13 & 0,556 & 0,2632 & 0,000 & Valid \\
X14 & 0,535 & 0,2632 & 0,000 & Valid \\
X15 & 0,644 & 0,2632 & 0,000 & Valid \\
\hline
\end{tabular}

Sumber: data diolah, 2020

Tabel di atas menunjukkan bahwa nilai $r$ hitung lebih besar dari $r$ tabel 0,2632, dengan nilai signifikansi sebesar 0,000 < 0,05 sehingga dapat disimpulkan bahwa semua instrumen pertanyaan variabel sikap (X1) dalam kuisioner dinyatakan valid. 
Tabel 4. Hasil Uji Validitas Variabel Norma Subjektif

\begin{tabular}{ccccc}
\hline Butir & r hitung & r tabel & signifikansi & Keterangan \\
\hline X21 & 0,761 & 0,2632 & 0,000 & Valid \\
X22 & 0,463 & 0,2632 & 0,000 & Valid \\
X23 & 0,743 & 0,2632 & 0,000 & Valid \\
X24 & 0,568 & 0,2632 & 0,000 & Valid \\
X25 & 0,612 & 0,2632 & 0,000 & Valid \\
\hline
\end{tabular}

Sumber: data diolah, 2020

Tabel di atas menunjukkan bahwa nilai $r$ hitung lebih besar dari $r$ tabel 0,2632, dengan nilai signifikansi sebesar 0,000 < 0,05 sehingga dapat disimpulkan bahwa semua instrumen pertanyaan variabel norma subjektif dalam kuisioner dinyatakan valid.

Tabel 5. Hasil Uji Validitas Variabel Kontrol Perilaku

\begin{tabular}{ccccc}
\hline Butir & r hitung & r tabel & signifikansi & Keterangan \\
\hline X31 & 0,834 & 0,2632 & 0,000 & Valid \\
X32 & 0,870 & 0,2632 & 0,000 & Valid \\
X33 & 0,854 & 0,2632 & 0,000 & Valid \\
X34 & 0,690 & 0,2632 & 0,000 & Valid \\
\hline \multicolumn{7}{l}{ Sumber: data diolah, 2020}
\end{tabular}

Tabel di atas menunjukkan bahwa nilai $r$ hitung lebih besar dari $r$ tabel 0,2632, dengan nilai signifikansi sebesar 0,000 < 0,05 sehingga dapat disimpulkan bahwa semua instrumen pertanyaan variabel control perilaku dalam kuisioner dinyatakan valid.

Tabel 6. Hasil Uji Validitas Variabel Niat

\begin{tabular}{ccccc}
\hline Butir & $\boldsymbol{r}$ hitung & $\boldsymbol{r}$ tabel & signifikansi & Keterangan \\
\hline YI & 0,746 & 0,2632 & 0,000 & Valid \\
Y2 & 0,854 & 0,2632 & 0,000 & Valid \\
Y3 & 0,814 & 0,2632 & 0,000 & Valid \\
\hline
\end{tabular}

Sumber: data diolah, 2020

Tabel di atas menunjukkan bahwa nilai $r$ hitung lebih besar dari $r$ tabel 0,2632, dengan nilai signifikansi sebesar 0,000 0,05 sehingga dapat disimpulkan bahwa semua instrumen pertanyaan variabel niat dalam kuisioner dinyatakan valid.

\section{Uji Reliabilitas}

Suatu konstruk atau variabel dikatakan reliabel jika memberikan nilai Cronbach's Alpha > 0,60 (Nunnally, 1960 dalam Ghozali, 2006). Hasil reliabilitas terhadap kuesioner pada masing masing variabel penelitian adalah sebagai berikut :

Tabel 7. Hasil Uji Reliabilitas Instrumen Penelitian

\begin{tabular}{cccc}
\hline Variabel & Cronbach's Alpha & r Kriteria & Keterangan \\
\hline Sikap & 0,646 & 0,60 & Reliabel \\
Norma Subjektif & 0,618 & 0,60 & Reliabel \\
Kontrol Perilaku & 0,829 & 0,60 & Reliabel \\
Niat & 0,728 & 0,60 & Reliabel \\
\hline
\end{tabular}

Sumber: data diolah, 2020

Berdasarkan tabel di atas dapat ditunjukkan bahwa nilai variabel attitude, subjective norm, perceived behavioral control, behavioral intention lebih besar dari 0,60 sehingga dapat dinyatakan reliabel. Hal tersebut membuktikan bahwa instrumen dari kuisioner yang digunakan untuk menjelaskan variabel 
sikap, norma subjektif, control perilaku dan niat dinyatakan handal atau dapat dipercaya sebagai alat ukur variabel.

\section{Uji Normalitas}

Uji normalitas dimaksudkan untuk mengetahui apakah residual yang diteliti berdistribusi normal atau tidak. Data dikatakan berdistribusi normal apabila nilai dari koefisien asymp sign (2-tailed) lebih besar dari alpha $=0,05$. Hasil uji normalitas pada penelitian ini dapat dilihat pada tabel berikut:

Tabel 8. Hasil Uji Normalitas One-sample Kolmogorov-Smirnov Test

\begin{tabular}{llr}
\hline & & $\begin{array}{c}\text { Unstandardized } \\
\text { Residual }\end{array}$ \\
\hline $\mathrm{N}$ & & 56 \\
Normal Parameters & ${ }^{\mathrm{n}}$ &, 0000000 \\
& Mean & 1,13404854 \\
Most Extreme & Std. Deviation &, 108 \\
Differences & Absolute &, 071 \\
& Positive &,- 108 \\
Test Statistic & Negative &, 108 \\
Asymp. Sig. (2-tailed) & &, $098^{\mathrm{c}}$ \\
\hline
\end{tabular}

a. Test distribution is Normal

Sumber: data diolah, 2020

Berdasarkan tabel di atas diperoleh nilai Asymp.Sig sebesar 0,098 > 0,05 maka dapat disimpulkan bahwa data dalam penelitian ini terdistribusi normal.

\section{Uji Multikolinearitas}

Tabel 9. Ringkasan Hasil Uji Multikolinearitas

\begin{tabular}{|c|c|c|c|}
\hline \multirow{2}{*}{\multicolumn{2}{|c|}{ Model }} & \multicolumn{2}{|c|}{ Collinearity Statistics } \\
\hline & & \multirow[t]{2}{*}{ Tolerance } & \multirow[t]{2}{*}{ VIF } \\
\hline 1 & (Constant) & & \\
\hline & $\mathrm{X} 1$ & 901 & 1,110 \\
\hline & $\mathrm{X} 2$ & ,930 & 1,075 \\
\hline & X3 & ,950 & 1,052 \\
\hline
\end{tabular}

a. Dependent Variable: $Y$

Sumber : data diolah, 202

Tabel di atas menunjukkan bahwa semua nilai Tolerance $>0,10$ dan semua nilai Variance Inflation Factor $(\mathrm{VIF})<10$, sehingga dapat disimpulkan hasil pengujian ini mengindikasikan bahwa model regresi yang digunakan dalam penelitian ini tidak terjadi gejala multikolinearitas, sehingga model dapat dipakai. 


\section{Uji Heteroskedastisitas}

Tabel 10. Hasil Uji Heteroskedastisitas

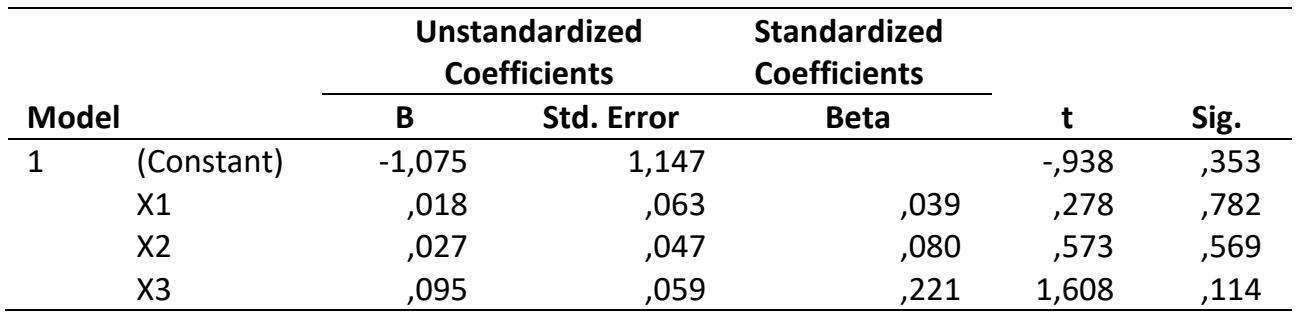

a. Dependent Variable: ABS_RES

Sumber: data diolah, 2020

Berdasarkan tabel di atas, dapat diketahui bahwa untuk variabel sikap mempunyai nilai signifikansi sebesar 0,782 >0,05, variabel norma subjektif mempunyai nilai signifikan sebesar 0,569 >0,05, dan kontrol perilaku memiliki nilai signifikansi sebesar 0,114 >0,05. Hasil tersebut menunjukkan bahwa data dalam penelitian tidak mengalami heteroskedastisitas dikarenakan nilai signifikansi masing-masing variabel lebih besar dari 0,05 .

\section{Analisis Regresi Linear Berganda}

Tabel 11. Uji Analisis Regresi Linear Berganda

\begin{tabular}{|c|c|c|c|c|c|c|}
\hline \multirow{2}{*}{\multicolumn{2}{|c|}{ Model }} & \multicolumn{2}{|c|}{$\begin{array}{l}\text { Unstandardized } \\
\text { Coefficients }\end{array}$} & \multirow{2}{*}{$\begin{array}{c}\text { Standardized } \\
\text { Coefficients } \\
\text { Beta }\end{array}$} & \multirow[b]{2}{*}{$\mathrm{t}$} & \multirow[b]{2}{*}{ Sig. } \\
\hline & & $\mathrm{B}$ & Std. Error & & & \\
\hline \multirow[t]{4}{*}{1} & (Constant) & 2,318 & 1,853 & & 1,251 & ,217 \\
\hline & $\mathrm{X} 1$ & 136 & 103, & 174 & 1,326 & 191 \\
\hline & $X 2$ & ,033 & 075 & ,056 & ,434 & ,666 \\
\hline & X3 & ,262 & ,096 & ,349 & 2,729 & ,009 \\
\hline
\end{tabular}

a. Dependent Variable: $Y$

Sumber : data diolah, 2020

Untuk mengetahui pengaruh antara sikap, norma subjektif, dan kontrol perilaku terhadap niat dilakukan dengan menggunakan persamaan regresi sebagai berikut:

$Y=2,318+0,136 X_{1}+0,033 X_{2}+0,262 X_{3}+e$

Analisis Koefisien Determinasi $\left(\mathbf{R}^{2}\right)$

Tabel. 12 Output Uji Koefisien Determinasi

\begin{tabular}{lrrrr}
\hline Model & R & R Square & \multicolumn{1}{c}{$\begin{array}{c}\text { Adjusted R } \\
\text { Square }\end{array}$} & \multicolumn{2}{c}{$\begin{array}{c}\text { Std. Error of the } \\
\text { Estimate }\end{array}$} \\
\hline 1 &, $437^{\mathrm{a}}$ &, 191 & 144 & 1,166 \\
\hline
\end{tabular}

a. Predictors: (Constant), X3, X2, X1

b. Dependent Variable: $Y$

Sumber : data diolah, 2020

Tabel di atas menunjukkan nilai Adjusted R Square sebesar 0,144. Hal ini menandakan bahwa variabel attitude, subjective norm, perceived behavioral control hanya dapat menjelaskan sebesar $14,4 \%$ variasi dari variabel Behavioral Intention. Sedangkan sisanya yaitu sebesar 85,6\% (100\% - 14,4\%) dijelaskan oleh faktor-faktor lain diluar model dalam penelitian ini. 


\section{Uji Statistik t (Uji Parsial)}

Tabel 11. Hasil Uji Statistik t

\begin{tabular}{|c|c|c|c|c|c|c|}
\hline \multirow{2}{*}{\multicolumn{2}{|c|}{ Model }} & \multicolumn{2}{|c|}{$\begin{array}{l}\text { Unstandardized } \\
\text { Coefficients }\end{array}$} & \multirow{2}{*}{$\begin{array}{c}\begin{array}{l}\text { Standardized } \\
\text { Coefficients }\end{array} \\
\text { Beta } \\
\end{array}$} & \multirow[b]{2}{*}{$\mathbf{T}$} & \multirow[b]{2}{*}{ Sig. } \\
\hline & & B & Std. Error & & & \\
\hline \multirow[t]{4}{*}{1} & (Constant) & 2,318 & 1,853 & & 1,251 & ,217 \\
\hline & $\mathrm{X} 1$ & 136 & 103 & 174 & 1,326 & 191 \\
\hline & $x 2$ & ,033 & 075 & ,056 & ,434 & 666 \\
\hline & X3 & 262 & ,096 & 349 & 2,729 & ,009 \\
\hline
\end{tabular}

a. Dependent Variable: $Y$

Sumber: data diolah, 2020

\section{a. Hubungan Sikap dan Niat}

Hasil Uji t pada tabel menunjukkan bahwa nilai signifikansi untuk variabel sikap sebesar 0,191 > 0,05 dan nilai beta sebesar 0,136 bernilai positif. Hasil perhitungan diperoleh angka thitung sebesar 1,326 < t tabel sebesar 2,00665. Maka dapat disimpulkan bahwa hipotesis ditolak yang artinya variabel sikap tidak berpengaruh terhadap niat dalam memperoleh gelar Chartered Accountant di Jawa Tengah.

\section{b. Hubungan Norma Subjektif dan Niat}

Hasil Uji t pada tabel menunjukkan bahwa nilai signifikansi untuk variabel Norma subjektif sebesar 0,669 > 0,05 dan nilai beta sebesar 0,033 bernilai positif. Hasil perhitungan diperoleh angka thitung sebesar 0,434 < t tabel sebesar 2,00665. Maka dapat disimpulkan bahwa hipotesis ditolak yang artinya variabel norma subjektif tidak berpengaruh terhadap niat dalam memperoleh gelar Chartered Accountant di Jawa Tengah.

\section{c. Hubungan Kontrol Perilaku dan Niat}

Hasil Uji t pada tabel menunjukkan bahwa nilai signifikansi untuk variabel Kontrol perilaku sebesar 0,009 > 0,05 dan nilai beta sebesar 0,262 bernilai positif. Hasil perhitungan diperoleh angka t hitung sebesar 2,729 > ttabel sebesar 2,00665. Maka dapat disimpulkan bahwa hipotesis diterima yang artinya variabel Kontrol perilaku berpengaruh terhadap niat dalam memperoleh gelar Charter Accountant di Jawa Tengah. Hal ini sejalan dengan temuan Dewi dan Budiasih (2017), Islamylia dan Mutia (2016), Solikhah (2014)

\section{Uji F (Simultan)}

Tabel 12. Hasil Uji Statistik F

\begin{tabular}{llcrrrr}
\hline \multirow{2}{*}{ Model } & \multicolumn{2}{c}{$\begin{array}{c}\text { Sum of } \\
\text { Squares }\end{array}$} & Df & Square & F & Sig. \\
\hline \multirow{2}{*}{1} & Regression & 16,695 & 3 & 5,565 & 4,091 &, $011^{\text {b }}$ \\
& Residual & 70,734 & 52 & 1,360 & & \\
& Total & 87,429 & 55 & & & \\
\hline
\end{tabular}

a. Dependent Variable: $Y$

b. Predictors: (Constant), X3, X2, X1

Sumber : data diolah, 2020

Berdasarkan tabel di atas diperoleh hasil dari $\mathrm{F}$ hitung sebesar 4,091 dan nilai F tabel sebesar 2,78 (df1 $(\mathrm{N} 1)=3$ dan df2 (N2)=56-3=53), hal tersebut menunjukkan bahwa nilai Fhitung sebesar 4,091 > dari nilai Ftabel sebesar 2,78. Sedangkan nilai signifikansinya sebesar $0,011<0,05$. Maka model regresi dapat digunakan untuk memprediksi behavioral intention atau dapat dikatakan bahwa hipotesis diterima, yaitu sikap, norma subjektif, dan kontrol perilaku berpengaruh secara simultan terhadap niat. 


\section{Pembahasan}

Variabel sikap tidak berpengaruh terhadap niat dalam memperoleh gelar Chartered Accountant di Jawa Tengah. Hal ini sejalan dengan penelitian Mihatinah dan Corynata (2016) bahwa responden tidak memiliki keyakinan bahwa dengan mengambil sertifikasi CA akan memberikan hal positif bagi mereka, sesuai dengan hasil uji hipotesis yang menyatakan bahwa sikap terhadap perilaku tidak berpengaruh terhadap niat mengambil sertifikasi CA. Bagi responden kepemilikan sertifkat ini juga bukan merupakan sebuah jaminan bagi kesuksesan mereka serta ada pandangan bahwa hal ini hanya menghamburkan uang saja. Hal serupa juga ditemukan oleh Bananuka et al (2019).

Variabel norma subjektif tidak berpengaruh terhadap niat dalam memperoleh gelar Chartered Accountant di Jawa Tengah. Hal ini sama dengan temuan Sinaga (2019) bahwa norma subjetif tidak berpengaruh terhadap niat. Hal serupa juga ditemukan oleh Ningsih dan Zaky (2016). Ini menandakan bahwa tekanan atau dorongan dari keluarga, teman dan sejawat tidak bisa mempengaruhi niat dalam pengambilan sertifikat CA (Chartered Accountant).

Variabel kontrol perilaku berpengaruh terhadap niat dalam memperoleh gelar Chartered Accountant di Jawa Tengah. Artinya, persepsi mahasiswa berpengaruh secara signifikan dan positif pada mahasiswa untuk cenderung memilih untuk mengambil sertifikat Chartered Accountant. Hasil penelitian ini didukung oleh penelitian terdahulu yang dilakukan oleh Gusti et.all (2013), dan Sugahara, Hiramatsu dan Boland (2009), Law, 2010; Solikah, 2014), yaitu persepsi memiliki pengaruh terhadap niat.

\section{SIMPULAN}

Variabel sikap tidak berpengaruh terhadap niat dalam memperoleh gelar Charter Accountant di Jawa Tengah. Variabel norma subjektif tidak berpengaruh terhadap niat dalam memperoleh gelar Charter Accountant di Jawa Tengah. Variabel kontrol perilaku berpengaruh terhadap niat dalam memperoleh gelar Chartered Accountant di Jawa Tengah. Hal ini bisa disimpulkan bahwa niat para responden dalam mengambil Chartered Accountant ternyata tidak dipengaruhi persepsi mereka mengenai baik buruknya tentang predikat ini. Bisa juga responden menganggap bahwa keberadaan kepemilikan sertifikat Charter Accountant tidak merasa yakin akan membawa hal yang positif bagi mereka. Sehingga niat memiliki sertifikat Chartered Accountant ini bisa karena adanya tuntutan dan kebutuhan dalam pekerjaan bagi para pekerja akuntan yang berkecimpung dalam bidang keuangan diera melenial ini. Dimana para akuntan bekerja penuh tantangan sehingga membutuhkan literatur dan informasi tentang Chartered Accountant.

\section{REFERENSI}

Ajzen, I. (1988). Attitudes, Personality, \& Behavior. Chicago: Dorsey Press.

Ajzen, I. (1991). The Theory of Planned Behavior. Organizational Behavior and Human Decision Processes, 50(2), 179-21.

Ajzen, I., \& Fishbein, M. (1975). Belief, Attitude, Intention, and Behavior: An Introduction to Theory and Research. Addison-Wesley, Reading, MA.

Anggraeni, R. (2013) Analisis Theory of Panned Behavior dalam Memprediksi Tax Compliance Wajib Pajak Pusat, Propinsi dan Kabupaten. Tesis. Universitas Jenderal Soedirman.

Bananuka, J., Kasera, M., Najjemba, G. M., Musimenta, D., Ssekiziyivu, B., \& Kimuli, S. N. L. (2019). Attitude: mediator of subjective norm, religiosity and intention to adopt Islamic banking. Journal of Islamic Marketing. 
Dewi, N. K. D. K., \& Budiasih, I. G. A. N. (2017). Pengaruh kecerdasan emosional, norma subjektif, dan kontrol perilaku pada minat berkarir mahasiswa pendidikan profesi akuntansi. E-Jurnal Akuntansi, 20(2), 1016-1045.

Felton, S., Dimnik, T., \& Northey, M. (1995). A theory of reasoned action model of the chartered accountant career choice. Journal of Accounting Education, 13(1), 1-19.

Fishbein, M. (1980). A theory of reasoned action: Some applications and implications. In M. M. Page (Ed.), Nebraska symposium on motivation (pp. 27).

Ikatan Akuntan Indonesia. (2014). Bersiap Diri Menyambut Pasar Tunggal ASEAN. Diakses melalui http://www.iaiglobal.or.id. Pada tanggal 16 November 2016, jam 14.35.

Islamylia, I., \& Mutia, E. (2016). Pengaruh Sikap, Norma Subjektif, Kontrol Perilaku, Motivasi Spiritual terhadap Minat Mahasiswa Akuntansi dalam Memilih Konsentrasi Akuntansisyariahdi Fakultas Ekonomi Universitas Syiah Kuala. Jurnal IImiah Mahasiswa Ekonomi Akuntansi, 1(1), 192-203.

Kotler, P., \& Keller, K. L. (2011). Manajemen Pemasaran, Edisi 13 Jilid 1 dan 2, Alih Bahasa : Bob Sabran, Erlangga, Jakarta.

Law, P. K. (2010). A theory of reasoned action model of accounting students' career choice in public accounting practices in the post-Enron. Journal of Applied Accounting Research, 11(1), 58-73.

Mahardhika, A. S., \& Zakiyah, T. (2020). Millennials' Intention in Stock Investment: Extended Theory of Planned Behavior. Riset Akuntansi dan Keuangan Indonesia, 5(1), 83-91.

Mihartinah, D., \& Coryanata, I. (2018). Pengaruh Sikap Terhadap Perilaku, Norma Subjektif, dan Kontrol Perilaku Persepsian Terhadap Niat Mahasiswa Akuntansi Untuk Mengambil Sertifikasi Chartered Accountant. Jurnal Akuntansi, 8(2), 77-88.

Mustikasari, E. (2007). Kajian empiris tentang kepatuhan wajib pajak badan di perusahaan industri pengolahan di surabaya. Simposium Nasional Akuntansi $X, 26,1-42$.

Ningsih, I. S. P., \& Zaky, A. (2014). Determinan Niat Mahasiswa Memilih Konsentrasi Akuntansi Dan Keuangan Syariah. Jurnal Ilmiah Mahasiswa FEB, 3(1).

Raminten, R. (2012). Pengaruh Motivasi Terhadap Minat Mahasiswa Akuntansi untuk Mengikuti Pendidikan Profesi Akuntansi (PPAk). Juraksi, 1(2).

Solikhah, B. (2014). An application of Theory of Planned Behavior towards CPA career in Indonesia. Procedia-Social and Behavioral Sciences, 164, 397-402.

Sugahara, S., \& Boland, G. (2006). Perceptions of the certified public accountants by accounting and non-accounting tertiary students in Japan. Asian Review of Accounting, 14(1), 149-167.

Yusup, A. H. (1994). Dasar-Dasar Akuntansi. Jilid 1. Edisi ke-4. Sekolah Tinggi Ilmu Ekonomi YKPN. Yogyakarta 